The University of Akron

\title{
IdeaExchange@UAkron
}

Proceedings from the Document Academy

University of Akron Press Managed

December 2016

\section{The Attitudes of Princess Nora University Students Towards Using Electronic Information Resources of the Library}

Latifah Alkahtani

University of North Texas, Princess Nora Bint Abdulrahman University, latefa-80@hotmail.com

Please take a moment to share how this work helps you through this survey. Your feedback will be important as we plan further development of our repository.

Follow this and additional works at: https://ideaexchange.uakron.edu/docam

Part of the Library and Information Science Commons, and the Regional Sociology Commons

\section{Recommended Citation}

Alkahtani, Latifah (2016) "The Attitudes of Princess Nora University Students Towards Using Electronic Information Resources of the Library," Proceedings from the Document Academy: Vol. 3 : Iss. 2 , Article 8. DOI: https://doi.org/10.35492/docam/3/2/8

Available at: https://ideaexchange.uakron.edu/docam/vol3/iss2/8

This Conference Proceeding is brought to you for free and open access by University of Akron Press Managed at IdeaExchange@UAkron, the institutional repository of The University of Akron in Akron, Ohio, USA. It has been accepted for inclusion in Proceedings from the Document Academy by an authorized administrator of

IdeaExchange@UAkron.For more information, please contact mjon@uakron.edu, uapress@uakron.edu. 


\section{Introduction}

After electronic information resources (EIR) were established and became widespread, dependence on the printed sources of the library was reduced, especially in the academic library because of the nature of the product. Radjagopal and Chinnasamy (2012) and Mizrachi (2010) concluded that the majority of students used the electronic resources more than the printed forms for their searching and academic purposes. Today, one of the most important functions of the academic library is to provide up-to-date, balanced, and comprehensive electronic resources for users from all disciplines. Using these resources provides a multitude of benefits in the academic environment. Global access for information is by far the greatest benefit for library users. However, with the growth of electronic resource use in the library, the need to investigate topics related to its use has increased. Therefore, studies such as measuring the usage, understanding the purposes for the use, and knowing the attitude and perception toward EIR have surfaced. The libraries' goals from these studies are to evaluate their collections, add more services or education, and implement strategies to allow students to benefit from these services.

Saudi Arabia universities' libraries are similar to academic libraries around the world; the use of technology in colleges in Saudi Arabia has significantly increased from 50\% in 2007 to $79 \%$ in 2009 (Communications and Information Technology Commission, 2009). Thus, the need for rapid updating of information is of great concern to students and faculties of Saudi universities.

The Saudi universities possess valuable EIRs that are used by students for their courses. Several studies have been conducted to evaluate the resources and their usage. One of these university libraries is the Princess Nora Bint Abdulrahman University Library (PNUL) in Riyadh. This library was able to develop its electronic collections in a short time. It opened in 2008 and continues to build its electronic collections; furthermore, it subscribes to many digital libraries, such as the Saudi Digital Library and the Academic Digital Library. However, building a strong electronic collection is not the goal of the institution. In other words, this library's purpose is not to have a huge digital resource, but merely to provide the resources that are of benefit to its students.

\subsection{Problem statement}

Many studies have investigated and measured the usage of electronic resources through universities' libraries, or investigated the attitudes towards the usage of the electronic resources, as well as the preferences and the purposes (Cribb \& Holt, 2012; Kadli \& Bhosale, 2013; Radjagopal \& Chinnasamy, 2012). These studies aimed to recognize and understand the reasons for using or avoiding the use of electronic resources. The academic libraries in Saudi Arabia have done few 
studies to evaluate using these resources. However, the situation at PNUL is different from other university libraries because it is still considered a new library that is developing its collections. Thus, as a relatively new library, it is suitable and timely to investigate the attitudes of its users about these electronic resources, the extent to which users are interested in utilizing them, and whether their attitudes have a relationship to their real usage. The findings will provide PNUL with a realistic image about reasons for attitudes toward the use of EIR and the preferences at the library.

\subsection{Research questions}

The aim of this study was to examine students' attitudes at PNU and if they affect their use of EIR at the library. Therefore, the study used the following questions to guide its investigation to answer the broad question:

1. To what extent are the students interested in using the electronic information resources of the library?

2. What are the reasons for interest or avoidance in the use of electronic resources of the library?

3. What is the frequency of use of electronic resources by PNU students?

4. What are the challenges faced by the students in their attempt to use electronic resources?

1.2.1 Research hypothesis. To answer the study questions, a hypothesis was tested to better understand the relationship between attitude of the students towards the electronic resources and the actual use of electronic resources.

The null hypothesis was there is no statistically significant relationship between attitudes of PNU students towards EIR and their real use of library EIR.

\subsection{Implications of the study}

The study derives its importance from the particular situation of the Princess Nora University Library. The library is considered a new library when compared to the other Saudi universities libraries, such as the library of King Saud University, which has been open for sixty years. Due to this fact, there is lack of studies about usage and attitude toward the PNU library resources. Moreover, the Library and Information Science Department in the university temporarily closed the graduate program because of Saudi Arabia's policy that encourages students to pursue graduate degrees outside the country. This policy could lead to decreases in the number of studies that could be investigated about the library. Thus, the results of this study could give the library administrators a clear picture about PNU students' attitudes towards electronic information. Moreover, investigating students' satisfaction with library services helps assess the library services and staff performance (Kadli \& Bhosale, 2013). 


\subsection{Objectives of the study}

The main objective of the study was to determine the students' attitudes at PNU and if the attitudes affect their use of EIR at the library. The specific objectives were:

- To determine the reasons for certain student attitudes about electronic resources of the library.

- To determine the purposes of using the electronic resources in the library.

- To analyze student behavior concerning using EIR.

\subsection{Conceptual definitions of the study}

1.5.1 Definition of attitude. The study listed many definitions for attitude in its general and specific definitions in the following sections; however, the study addressed the summary that was drawn from all the listed definitions suitable for the study, which is the position that a student takes, whether positive or negative, of using the EIR of the library.

1.5.2 Definition of electronic information resources. Information resources provided by PNUL in electronic forms for all users, and it was represented as EIR (Gakibayo et al., 2013).

\subsection{Background}

PNUL has been managed by the Dean of Library Affairs since April 2008. The dean has a considerable staff that works closely with her, and this department is responsible for all matters related to libraries and information at all local, regional, and international levels, as well as overseeing PNU participation in local and international conferences (Princess Nora University Library [PNUL], 2015).

Because of the lack of studies addressing PNUL, the only source that the study depended on to increase the knowledge about the library is the PNUL website, which did not have a wealth of information.

The library provides services to more than 42,000 students in fifteen different colleges, yet this number of students was not considered to be too many for the university to assist because of the directive of the Ministry of Higher Education and its recent policy to accept a large number of female students. The Saudi government has undertaken to make PNU the largest women-only university in the world and has allotted major financial and human resources in order to realize this goal (Saudi Arabian Culture Mission [SAMCM], 2012). The Dean of Library Affairs has provided EIR for its users to serve the following purposes:

1. Support the educational process.

2. Employ technology to facilitate access to sources of information.

3. Invest in specialized human resources. 
4. Supply EIR in various disciplines to serve the community.

5. Provide excellence in research and development programs at PNUL (PNUL, 2015).

To achieve these goals, the Dean of Library Affairs oversees many major and minor departments. The departments that are responsible for providing electronic resources for PNUL are the Information Sources Development Department and Information Databases Department. They provide access to all sources of EIR in all disciplines for faculty, employees, students, scholars, and researchers. Furthermore, they supervise the Saudi Digital Library within the university by activating subscriptions to the Saudi Digital and Academic Digital Libraries. The two departments have additional tasks, including:

1. Communication with publishers and suppliers to incorporate internet protocol (IP) for databases, to ensure the validity of these databases on the university website, and to inform suppliers in case of disruptions.

2. Interaction between the colleges and Ministry of Education to address the needs of college databases.

3. Creation of courses for using electronic resources, including training for users (PNUL, 2015).

\section{Literature review}

\subsection{Attitude and electronic information resources conceptions}

Today, electronic information resources (EIR) have become an essential part of the library's collections and services; therefore, a number of relevant studies have been done on attitudes towards using electronic resources in the academic environment. Studies have addressed the two concepts of attitude and electronic resources. Alkhanak and Azm (2011) defined attitude in general as the individuals' responses in preferential ways based on their beliefs. The precise definition related to this study was defined by Ngozi et al. (2014), who defined it as the students' reactions to using electronic resources based on their beliefs, their assumptions, and people's opinions. Moreover, Alkhanak and Azm (2011) described student attitude in the academic environment as the electronic resources evaluation in positive or negative ways that influence the student's learning process. Thus, the attitude toward use of EIR is simply the tendency that the student takes, positively or negatively, for using the EIR of the library. However, Fishbein and Ajzen (1975) stated that many concepts could be categorized under the concept of attitude, such as opinion, liking, and satisfaction. On the other hand, the second concept of the study of EIR are what Radjagopal and Chinnasamy (2012) defined as "material (data or programs) encoded for manipulation by computerized device, and this material may require the use of a peripheral directly connected to a computerized device" (p. 149). These would 
include resources, such as a CD-ROM drive or a connection to a computer network or the Internet. The resources could be accessed on the web, on, or off campus. For more clarification, the EIR of the library are "those library resources that can only be accessed via the use of computing devices such as computers, tablets, and smart phones" (Ukachi, Onuoha, \& Nwachukwu, 2014, p. 334). To sum up, information resources that PNUL provides in electronic form for all its users (Gakibayo et al., 2013) was the focus of this study.

\subsection{The relationship between students' attitudes towards electronic information resources and the usage}

In addition to reviews and studies that addressed attitude and electronic information concepts, there are studies that have investigated the relationship between attitude of the students, faculty, researchers, and librarians toward using the electronic resources, information services, and using the library. Ngozi et al. (2014) conducted a recent study that investigated students' attitude toward electronic resources. The study indicated that EIR were under-utilized in general because of the negative attitude of the students toward using the libraries electronic resources. Wu and Chen (2012) conducted a study to understand how graduate students perceive and mange electronic information resources. They concluded that students prefer using the library web site for relevant documents, and then they use the internet. Furthermore, the major problems that graduate students face during the search process are the inability to retrieve relevant material, feeling confused because of the various search methods of databases, and slow Internet connections off campus on the library proxy. Gowda and Shivalingaiah (2009) stated that doctoral students likely are the prevalent researchers that rely on digital resources, especially databases. By using databases, they can comprehensively cover the literature in their fields. Radjagopal and Chinnasamy (2012) also conducted a similar study to analyze the user attitude and approach towards services in an academic library and electronic resources. They found that 78 percent of the respondents used databases, and 48 percent used the Internet for their research paper.

Thus, researchers are interested in students in their different categories, whether they are graduate students or undergraduates. The reasons for this choice are:

1. The findings in these studies will help improve students' information skills so they can meet their information needs in effective way.

2. Students are more likely have a lack of awareness for library services than other groups and need more workshops and information literacy programs (Saved, Bhatti, \& Khan, 2014).

3. Investigating students' satisfaction towards library services helps assess the library services and staff performance (Kadli \& Bhosale, 2013). 
4. By understanding academic information, behavior of the students and their preferences, the awareness of the librarians and educators will increase towards students' perspective, which will create student-centered services (Mizrachi, 2010).

\subsection{Theoretical perspective}

Attitude domain has many theories and models used to understand certain phenomena, and most of these theories have similar features. For example, they identify both determinants of attitude and the consequences of attitude. Also, these theories provide a conceptual vocabulary to help organize empirical observations of behavior and beliefs (Pratkanis, Breckler, \& Greenwald, 1989). Moreover, the importance of applying theories or models that is related to the attitude of certain groups is what Zint (2002) confirmed when he stated that the importance of attitude-behavior theories and models is their ability to predict behavior, which will in turn improve library services; thus, researchers are interested in applying models in their studies.

The theoretical framework of the study was based on the Theory of Reasoned Action (TRA) that was developed by Fishbein and Ajzen. This theory indicates that attitude and subject norm are the main reason for an individual's behavior (Chen et al., 2012). The theory has been used many in a variety of fields, such as information services, education, and technology in order to understand human behavior, because theory usually tries to explain a specified set of phenomena (Case, 2012). The first part of the explanation fits this study. Thus, the attitude that emerges from the students' beliefs, opinions, feelings, and ideas is the main reason for interest about or avoiding use of the electronic resources in the library. TRA is derived from a social psychology setting and is concerned with prediction of behavior and attention because it covers prediction of attitude and behavior and explains it scientifically.

TRA consists of three general constructs:

- Behavioral intention (BI)

- Attitude (A)

- $\quad$ Subjective norm (SN)

TRA suggests that a person's behavioral intention depends on the person's attitude about behavior and subjective norm. Behavioral intention measures a person's relative strength of intention to perform a behavior. In other words, a person's volitional, or voluntary behavior is predicted by the attitude toward that behavior and how that person thinks other people would view him if a behavior was performed. A person's attitude, combined with subjective norms, forms behavioral intention (Fishbein \& Ajzen, 1975). For example, a student may have a belief that using databases is hard and complex, or there is no need to use them in research. Seeing other students who avoid using databases and have good grades 
is influenced by the beliefs and actions of people, will likely influence in behavioral intention in using databases in the future.

Student attitude toward databases combined with the subjective norms about databases, each with their own weight, will lead the student to the intention to avoid using databases, which will then lead to actual behavior. Behavioral intention is a function of both attitudes toward a behavior and subjective norms toward that behavior, which has been found to predict actual behavior.

\section{Methodology}

\subsection{Population and sample}

The study investigated the attitude of PNU students toward the EIR of the library. The student group signified all students, both undergraduate and graduate. The university population was entirely composed of female students because it is women-only university with 42,000 students in fifteen different colleges. However, because of the policy that encourages students to pursue graduate degrees abroad, many of the graduate programs have been closed, with the exception of Arabic Language studies and Islamic studies. This policy has led to a major disparity between graduate students and undergraduate students. The graduate students included the following:

- 282 graduate students in Islamic Studies Department

- 210 graduate students in Arabic Language Department (Electronic Services Department in PNU, 2013).

The total included in the study were 492 graduate students and 41,508 undergraduate students. The study excluded the graduate students of the two departments so that the population would be more convergent to this study and the results would be close to the majority of the population of the university and could be generalized. That placed the study focus on the undergraduate student category only. Consequently, there was focus on some properties of the undergraduates, such as age category and variety of disciplines in the university. Thus, the population of the study was all the undergraduate students at PNU.

The random sample method was appropriate for this study because the population was somewhat analogous due to the fact that all the population belonged to the same gender, and all of them were undergraduates. The only differences were the major being pursued and the year in school from freshman year to senior, so the systematic random sample type was specifically the best random sample method for the study (Creswell, 2014) and the sample size of 380 was based on the Krejcie \& Morgan table sample size. 


\subsection{Research method}

The survey method used was a questionnaire adapted from Ukachi, Onuoha, \& Nwachukwu (2014) and modified by the author to serve the purposes of the study. The questionnaire consisted of 30 questions that were divided into three sections: first was demographic information; second was the students' use of EIR in the library; and third was the students' attitudes towards these resources. A total number of 380 copies of the questionnaire were distributed to undergraduate students in Spring 2016. As a result, 274 were returned and 19 copies were found unusable, making the usable number of the copies 255 .

\section{Results}

\subsection{First part of the questionnaire (demographic information)}

This section covered questions one to five listed on the questionnaire. Figure 1 shows the percentage and frequencies of the participants' distribution. The majority of the participants were from the Preparatory Year College at 52 $(20.4 \%)$, followed by Arts College, at 44 (17.3\%). The Business \& Administration College was 39 participants (15.3\%), and the Science College was close, with 38 participants (14.9\%). The lowest participation was from the Medicine Colleges, with only 3 (1.2\%).

Figure 1. Distribution of sample according to college (percentages)

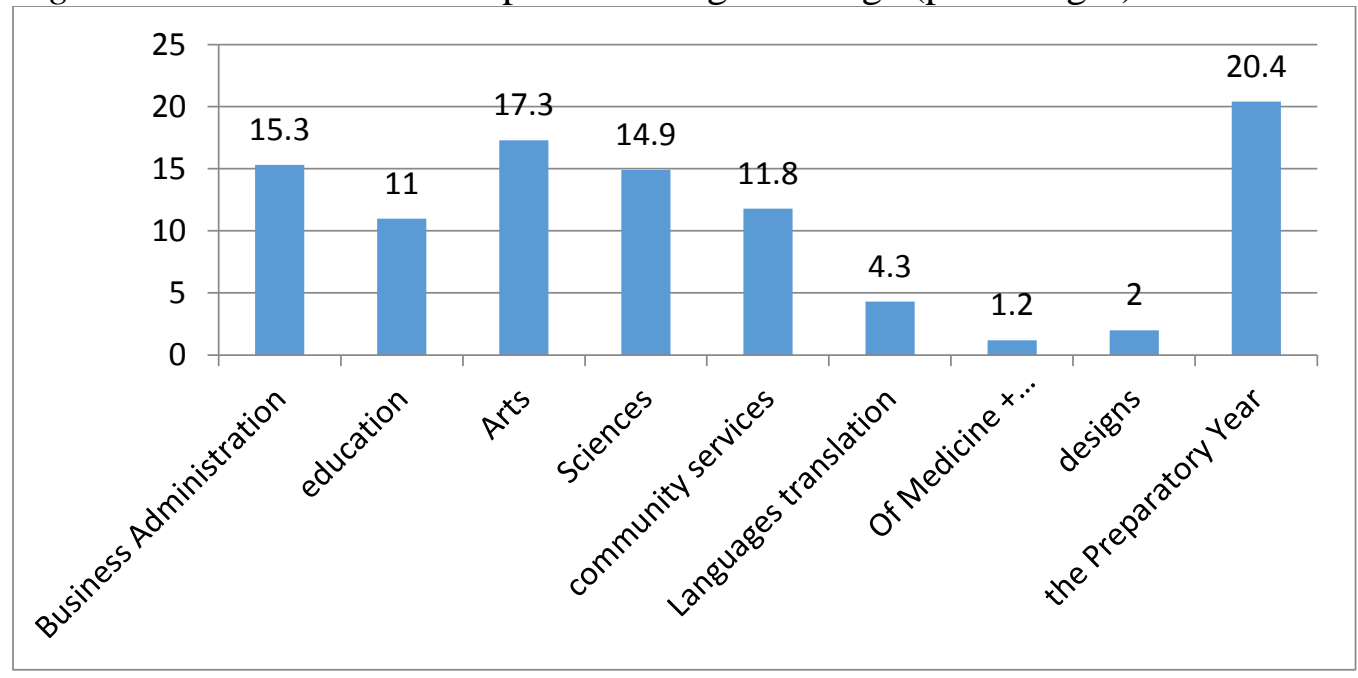

The second question in this section covered participants' discipline, as shown in Figure 2, It showed that the preparatory year was the highest with 58 students $(22.7 \%)$, then the library students with $26(10.2 \%)$, special education and information systems were (7.8\%) and (7.1\%). Economy was 16 (6.3\%), English15 
(5.9\%), Business administration and social services each with 14 (5.5\%), and biology $13(5.1 \%)$. Chemistry and Islamic studies had the same amount of the participants, 6 each (2.4\%). Autism and behavioral disturbances, physics, and textile and costume had the same percentage of participation, which made up $0.4 \%$ each.

Figure 2. Distribution of sample according to discipline (percentages)

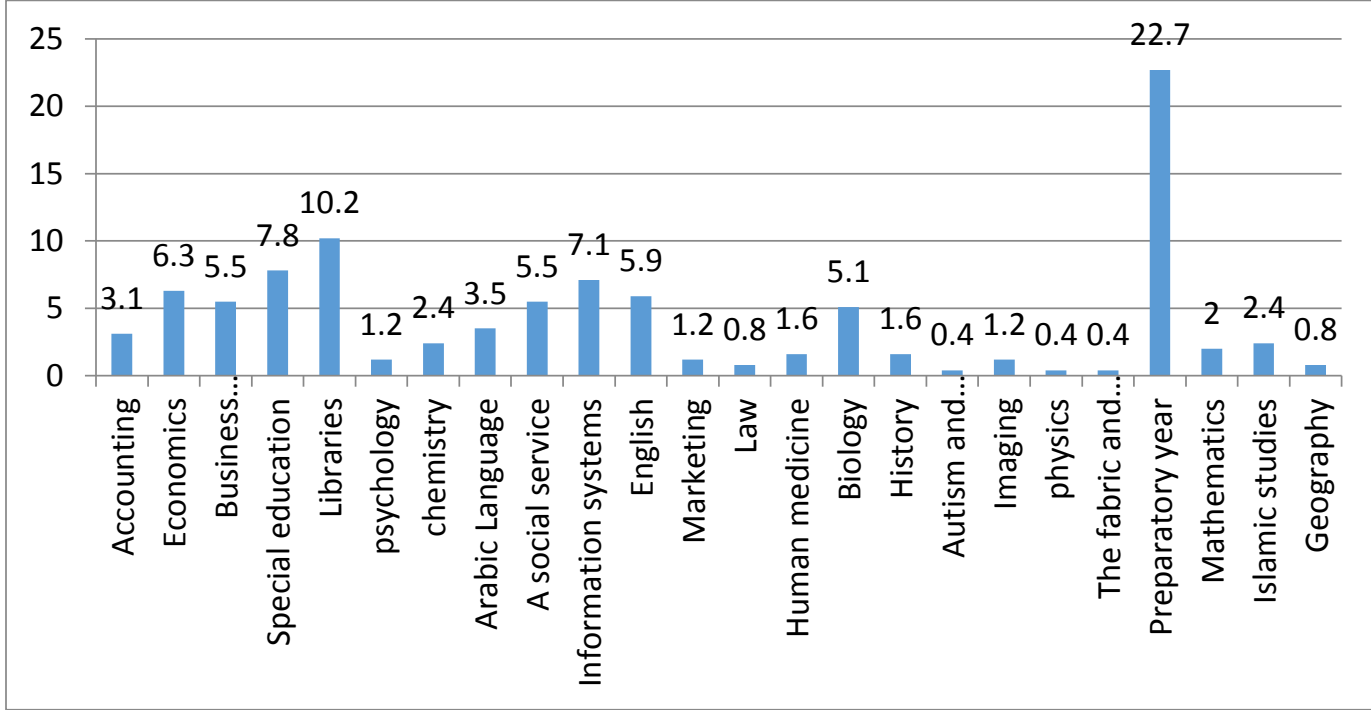

The participants were asked about their current year of school, and 93 of them reported they were in their first year as freshman $(36.5 \%)$, while the second highest group were seniors at $54(21.2 \%)$, followed by 50 junior participants $(19.6 \%)$, then sophomore with 43 students $(16.9 \%)$. This information is shown in Figure 3.

Figure 3. Distribution of sample according to current year of study (percentages)

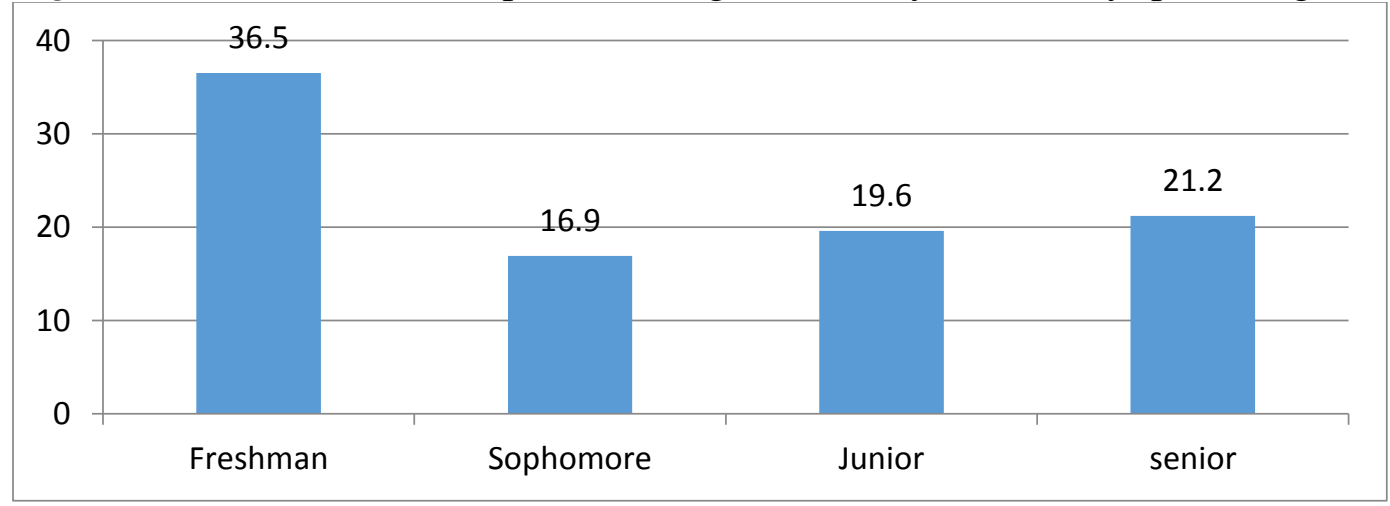


The fourth question in this section was if the students use the EIR of the library. Results showed 251 (98.1\%) of them answered yes, while four answered no. Figure 4 shows these results.

Figure 4. The usage of EIR of the library by the students (percentages)

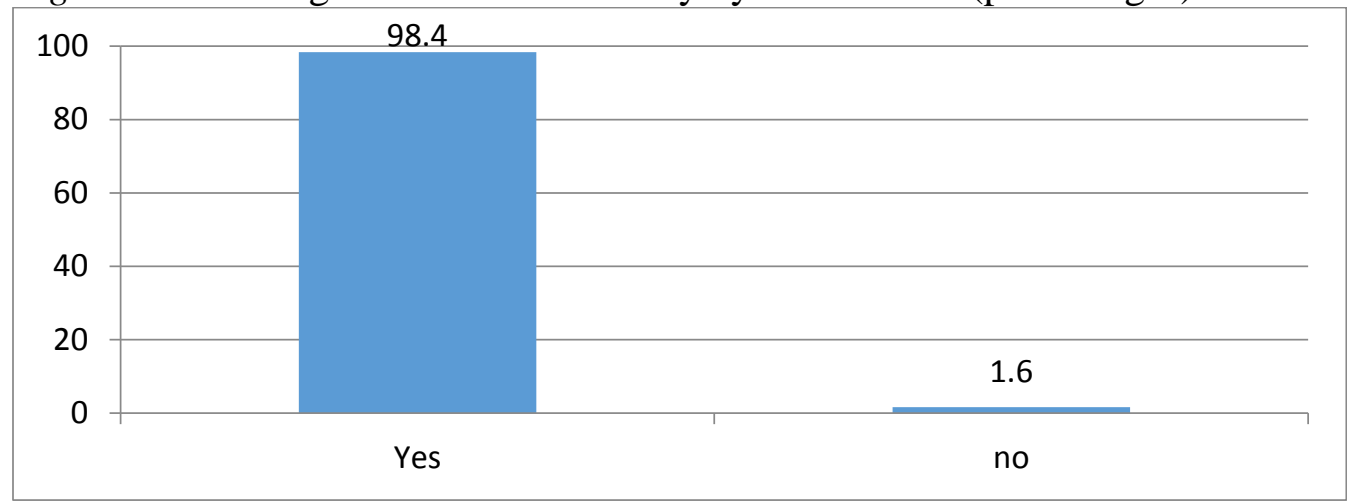

The last question in the demographic section was the amount of usage per week; in this case, 125 of the participants (49\%) stated that they used EIR less than one hour, $115(45.1 \%)$ used it two to four hours weekly, $10(3.9 \%)$ responded that they use it between 5 and 9 hours weekly, while only one participant used it 10 hours or more. These results are shown in Figure 5.

Figure 5. Average hours of EIR use at library (percentages)

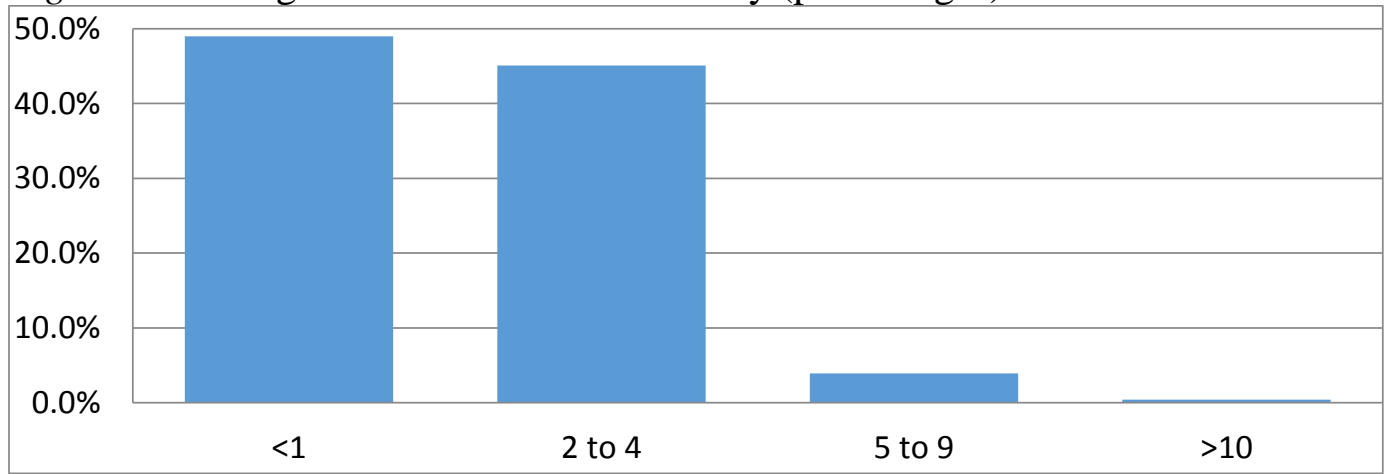

\subsection{Second part of the questionnaire (reasons for using EIR)}

This section consisted of 12 questions designed to determine the extent of the students' uses for the library's EIR. It provided different options for the academic purposes and use. The responses are in Appendix A, which produced items (in order) of $1,5,8,7,4,10$, and 11, with mean scores greater than 2.9. This implied that most usage is for nonacademic purposes, such as chatting, sending e-mail, and following blogs, except item 1 that had the greatest at 3.9, which indicated 
student use of EIR for finding materials for their papers. However, the overall mean score for all the 12 items was 3.2 which was greater than the acceptable average of 2.5; therefore it could be said that the EIR of PNUL were adequately used.

\subsection{Third part of the questionnaire (attitudes towards using EIR)}

The numbers Showed slight differences from the students' utilization, the only two items (11 and 12) out of the entire 13 items their mean scores were lower than 3 , but were more than the acceptable average of 2.5. The rest of the 11 items had scores means above 3.18. Furthermore, the greatest mean score was statement 6 (I am convinced that the use of electronic information sources in the library will improve my performance academic) at 4. 14, which indicated the student awareness of the importance of the library EIR. Overall, evidence from the ratios, frequencies, means and standard deviations showed that students at PNUL had a positive attitudes towards library EIR. (See Appendix B for more details.)

\subsection{Fourth part of the questionnaire (relationship between attitudes and use)} To assess the relationship between these variables and answer the null hypothetical statement that no statistically significant relationship between attitudes of PNUL students towards EIR and their real use of library EIR existed, Pearson's correlation was run. The results are presented in Table 1, which shows there was a moderate positive correlation between the attitudes and the use (0.520), implying that the attitudes towards the use could influence their actual use.

Table 1. The correlation between the variables

\begin{tabular}{|l|l|l|l|}
\hline Variables & attitude & EIR Use \\
\hline \multirow{4}{*}{ The attitude } & Pearson Correlation & 1 & $.520^{* *}$ \\
\cline { 2 - 4 } & Sig. (2-tailed) & & 0.000 \\
\cline { 2 - 4 } & $\mathrm{N}$ & 251 & 251 \\
\hline EIR use & Pearson Correlation & $.520^{* *}$ & 1 \\
\cline { 2 - 4 } & Sig. (2-tailed) & 0.000 & \\
\cline { 2 - 4 } & $\mathrm{N}$ & 251 & 251 \\
\hline
\end{tabular}

** Correlation is significant at the 0.01 level (2-tailed).

\section{Discussion of findings}

The findings revealed that the EIRs of the library academically were still at a moderately utilized level; however, they were sometimes lower. For instance, out of 12 options listed to measure to what extent the students use EIRs, the highest percentage was for the statement: "I use the library's EIR to source materials for 
research/writing project", with 51\% and was repeated as frequent use 130 times. Other academic purposes, such as E-journal service that the library provides through subscriptions only reached to 28 responses for frequent use, 74 respondents did not use it at all, and 99 respondents of the sample said they rarely used it. This result was consistent with what Ivwighreghweta (2012) concluded when he referred the paucity of e-journals use of the library for the majority of the respondents due to the lack of undergraduate awareness about this service. Furthermore, retrieving current literature by using library EIRs attained only $2.7 \%$ vs. $14.9 \%$ of the sample who did not use it at all. Furthermore, only $2.7 \%$ of the students used the EIRs of the library to search for literature, while $14.9 \%$ of the sample did not think to use EIRs for that.

That is what Ukachi, Onuoha, and Nwachukwu (2014) pointed out in their study by concluding that students do not benefit from library EIR in an adequate way. Moreover, the results of the study revealed the students were using the Internet at the library to communicate with others, more than other e-sources and similar to what Safdar, Mahmood, and Qutab (2010) indicated, which was that most students have a positive attitude towards using the provided internet on campus to communicate.

Furthermore, the results of the second part of the questionnaire that related to the students attitudes showed a high level for EIR, with an overall mean score for all of 13 at 3.57, and this mean score was greater than the use statements mean scores of 3.2. The results also showed there was a relationship between the use and attitudes even if it was considered moderate; however, the statements that had a positive attitude towards he usage had the greater means and percentages, such as $49 \%$ of the respondents appreciating using EIR, and $48.6 \%$ saying the use of EIR in the library would improve their academic performance. This could be attributed to the willingness of the students to accept electronic resources, even if they do not use them immediately (Wu \& Chen, 2010).

\section{Conclusion}

This study was an attempt to explore students' trends of new services, the whole situation is new for the students, including the university lifestyle and education system, as well as for the university management. However, the study has established that EIR of the library have been used moderately by the students; in contrast, the students showed a high acceptance of these resources. At this point, the PNUL management should launch and study the results of this investigation to try to reduce the gap between the attitudes and the use by students. That should open the door for more studies about the high level of awareness and overwhelming importance of using library EIR and the shortage of actual use. 


\section{References}

Alkhanak, S., \& Azmi, I. (2011). Information technology usage and attitudes towards online resources-Students perspective. African Journal of Business Management, 5(7), 2582-2589.

Anaraki, L., \& Babalhavaeji, F. (2013). Investigating the awareness and ability of medical students in using electronic resources of the integrated digital library portal of Iran. The Electronic Library, 31(1), 70-83.

Case, D. (2012). Looking for information: A survey of research on information seeking, needs, and behavior (3rd edition). Bingley, UK: Emerald Group Publishing Limited.

Creswell, J. W., \& Clark-Plano, V. L. (2011). Designing and conducting mixed methods research (2nd edition). Thousand Oaks, CA: Sage.

Creswell, J. (2014). Research Design: Qualitative, Quantitative, and Mixed Methods Approaches. London, UK: Sage.

Communications \& Information Technology Commission. (2009). Annual report. Retrieved from http://www.citc.gov.sa/en/mediacenter/annualreport

Cribb, G., \& Holt, I. (2012). Student engagement and library use: An examination of attitudes towards use of libraries and information amongst undergraduate students at a Turkish University library. Paper presented at the 33rd IATUL conference, Singapore. Retrieved from http://docs.lib.purdue.edu/iatul/2012/papers/22/

Fishbein, M., \& Ajzen, I. (1975). Belief, attitude, intention, and behavior: An introduction to theory and research. Boston, MA: Addison-Wesley.

Gowda, V., \& Shivalingaiah, D. (2009). Attitude of research scholars towards usage of electronic information resources: a survey of university libraries in Karnataka. Annals of Library \& Information Studies, 56(3), 7.

Ivwighreghweta, O. (2012). Attitude of undergraduate students towards the use of open access journals at the Delta State University, Abraka, Delta State, Nigeria. The Information Technologist, 9(2), 140-150.

Jamieson, S. (2004). Likert scales: How to (ab)use them. Medical Education,38, $1212-1218$

Kadli, J., \& Bhosale, S. K. (2013). Students' view on library in ICT environment: A study of Lala Lajpatrai College, Mumbai. International Journal of Information Dissemination \& Technology, 3(3), 203-207.

Kelley, K. B., \& Orr, G. H. (2003). Trends in distant student use of electronic resources: A survey. College \& Research Libraries, 64(3), 176.

Mizrachi, D. (2010). Undergraduates' academic information and library behaviors: Preliminary results. Reference Services Review, 38(4), 571580.

Ngozi, B.U., Onuoha, D., \& Victor N Nwachukwu. (2014). Students' attitudes as a determining factor to electronic information resources use in university 
libraries in southwest Nigeria. DESIDOC Journal of Library \& Information Technology, 34(4), 333-341.

Okeke, I., Lucky, O., \& Nwabu, E. (2013). Students' attitude towards the use of reference and information services (RIS) in academic Libraries in Nigeria. International Journal of Library and Information Science, 5(10), 335-341

Petty, R. E., Wegener, D. T., \& Fabrigar, L. R. (1997). Attitudes and attitude change. Annual Review of Psychology, 48, 609-647.

Pratkanis, A., Breckler, S., \& Greenwald, A. (1989). Attitude structure and function. New York: Psychology Press.

Radjagopal, V., \& Chinnasamy, K. (2012). Users attitudes and approaches towards e-resources and services in the Academic Library of Puducherry Union Territory: A study. Journal of Advances in Library and Information Science, 1(4), 149-152.

Ray, K., \& Day, J. (1998). Student attitudes towards electronic information resources. Information Research, 4(2). Retrieved from http://informationr.net/ir/4-2/paper54.html

Safdar, M., Mahmood, K., \& Qutab, S. (2010). Internet use behavior and attitude of college students: A survey of Leadership Colleges' Network. Library Philosophy and Practice, 366.

Saudi Arabian Cultural Mission. (2012). The advancement of women. Retrieved from http://www.sacm.org/ArabicSACM/pdf/women_front_web.pdf

Saved, M. W., Bhatti, R., \& Khan, S. A. (2014). Satisfaction with Library Services: A Survey of Post Graduate Students at Nishtar Medical College, Multan.Pakistan Library \& Information Science Journal, 45(3), 77-83.

Sivathaasan,N., Murugathas, K., \& Chandrasekar, K. (2014). Attitude towards the usage of electronic information resources in Medical Library, University of Jaffna, Sri Lanka. Information and Knowledge Management, 4(1). Retrieved from http://iiste.org/Journals/index.php/IKM/article/view/10383

Sutton, S. (1998). Predicting and explaining intentions and behavior: How well are we doing? Journal of Applied Social Psychology, 28, 1317-1338

Tang, Y., \& Tseng, H. W. (2014). Distance students' attitude toward library help seeking. Journal of Academic Librarianship, 40(3-4), 307-312.

Tenopir, C. (2003). Use and users of electronic library resources: An overview and analysis of recent research studies. Council on Library and Information Resources, Washington, DC. Retrieved from http://clir.org/pubs/reports/pub120/pub120.pdf

Valentine, B. (1993). Undergraduate research behavior: Using focus groups to generate theory. Journal of Academic Librarianship, 19(5), 300-304.

Vezzosi, M. (2009). Doctoral students' information behaviour: An exploratory study at the University of Parma (Italy). New Library World, 110(1), 6580 . 
Wu, M., \& Chen, S. (2012). How graduate students perceive, use, and manage electronic resources. Aslib Proceedings, 64(6), 641-652.

Zint, M. (2002). Comparing three attitude-behavior theories for predicting science teachers' intentions. Journal of Research in Science Teaching, 39(9), 819844. 


\section{Appendix A: Usage of library EIR by PNU students}

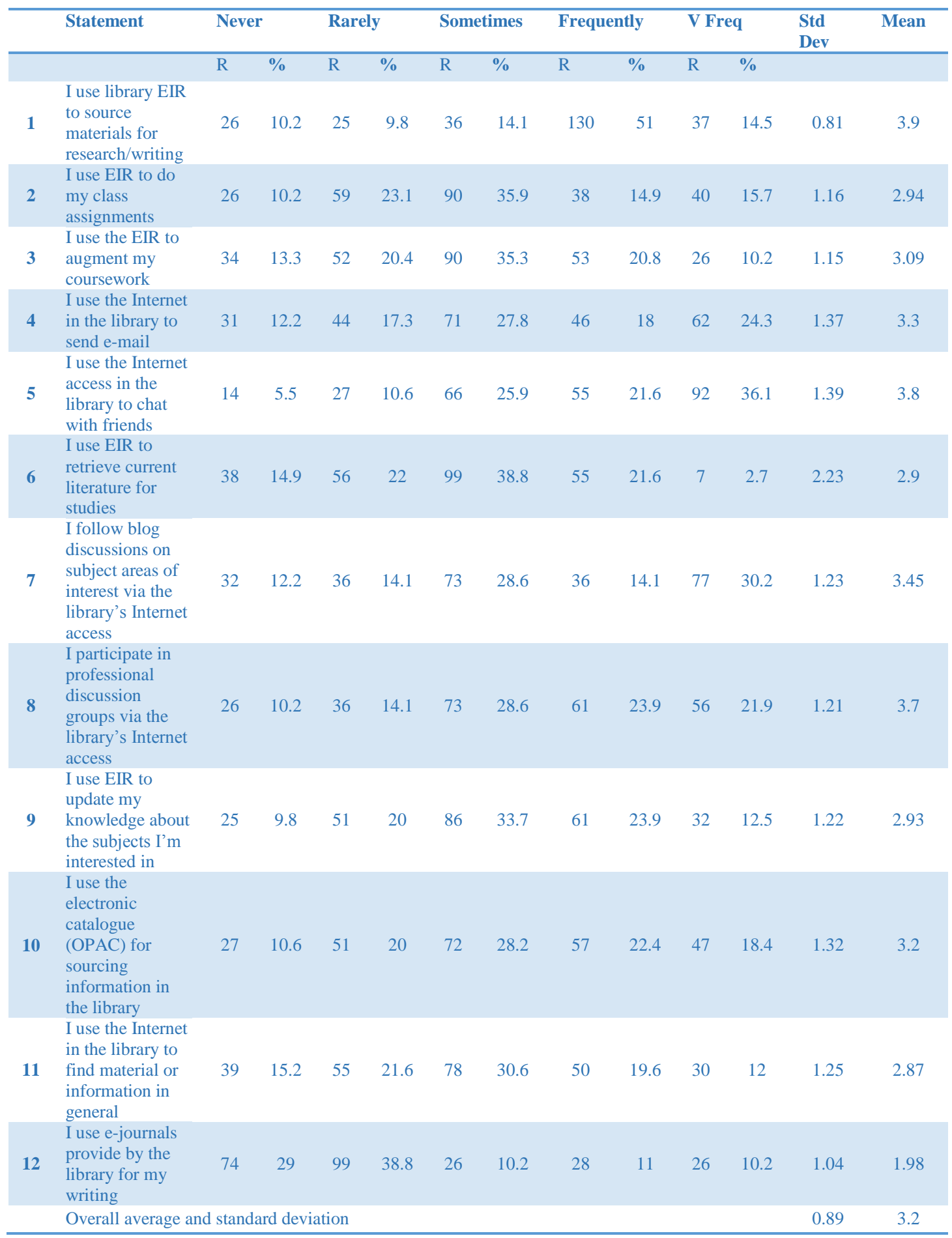


Appendix B: Attitudes of PNUL students towards EIR use

\begin{tabular}{|c|c|c|c|c|c|c|c|c|c|c|c|c|c|}
\hline & \multirow[t]{2}{*}{ Statements } & \multicolumn{2}{|c|}{$\begin{array}{c}\text { Str } \\
\text { Disagree }\end{array}$} & \multicolumn{2}{|c|}{ Disagree } & \multicolumn{2}{|c|}{ Neutral } & \multicolumn{2}{|c|}{ Agree } & \multicolumn{2}{|c|}{ Str Agree } & \multirow[t]{2}{*}{ Std Dev } & \multirow[t]{2}{*}{ Mean } \\
\hline & & $\mathrm{R}$ & $\%$ & $\mathrm{R}$ & $\%$ & $\mathrm{R}$ & $\%$ & $\mathrm{R}$ & $\%$ & $\mathrm{R}$ & $\%$ & & \\
\hline 1 & $\begin{array}{l}\text { Learning to use EIR } \\
\text { has been fascinating }\end{array}$ & 3 & 1.2 & 5 & 2 & 56 & 22 & 125 & 49 & 64 & 25.1 & 0.81 & 3.95 \\
\hline 2 & $\begin{array}{l}\text { I find using EIR } \\
\text { easier than using } \\
\text { printed resources }\end{array}$ & 1 & 0.4 & 17 & 6.7 & 37 & 14.5 & 109 & 42.7 & 90 & 35.3 & 0.90 & 4.06 \\
\hline 3 & $\begin{array}{l}\text { I have the initiative } \\
\text { and motivation to } \\
\text { learn and use EIR }\end{array}$ & 1 & 0.4 & 11 & 4.3 & 42 & 16.5 & 131 & 51.4 & 69 & 27.1 & 0.81 & 4.00 \\
\hline 4 & $\begin{array}{l}\text { I appreciate using } \\
\text { EIR for my } \\
\text { academic works }\end{array}$ & 6 & 2.4 & 12 & 4.7 & 41 & 16.1 & 125 & 49 & 70 & 27.5 & 0.91 & 3.94 \\
\hline 5 & $\begin{array}{l}\text { I see the use of EIR } \\
\text { as relevant for } \\
\text { academic purposes }\end{array}$ & 3 & 1.2 & 9 & 3.5 & 42 & 16.1 & 117 & 45.9 & 84 & 32.9 & 0.86 & 4.06 \\
\hline 6 & $\begin{array}{l}\text { I am convinced that } \\
\text { the use of EIR in the } \\
\text { library will improve } \\
\text { my academic } \\
\text { performance }\end{array}$ & 2 & 0.8 & 8 & 3.1 & 31 & 12.2 & 124 & 48.6 & 89 & 34.9 & 0.81 & 4.14 \\
\hline 7 & $\begin{array}{l}\text { I prefer using the } \\
\text { library catalog cards } \\
\text { to OPAC }\end{array}$ & 13 & 5.1 & 34 & 13.3 & 63 & 24.7 & 100 & 39.2 & 44 & 17.3 & 1.08 & 3.50 \\
\hline 8 & $\begin{array}{l}\text { Augmenting my } \\
\text { lecturer's notes and } \\
\text { handouts with the } \\
\text { use of library EIR } \\
\text { seems relevant to me }\end{array}$ & 4 & 1.6 & 29 & 11.4 & 77 & 30.2 & 102 & 40 & 43 & 16.9 & 0.95 & 3.59 \\
\hline 9 & $\begin{array}{l}\text { The search method } \\
\text { for EIR does not } \\
\text { make its use } \\
\text { interesting to me }\end{array}$ & 13 & 5.1 & 52 & 20.4 & 70 & 27.5 & 75 & 29.4 & 45 & 17.6 & 1.13 & 3.30 \\
\hline 10 & $\begin{array}{l}\text { Using EIR is not as } \\
\text { exciting as using } \\
\text { printed resources }\end{array}$ & 17 & 6.7 & 67 & 26.3 & 58 & 22.7 & 79 & 31 & 34 & 13.3 & 1.15 & 3.18 \\
\hline 11 & $\begin{array}{l}\text { My friends' } \\
\text { experience with } \\
\text { library EIRs doesn't } \\
\text { encourage me to use } \\
\text { it }\end{array}$ & 27 & 10.6 & 89 & 34.9 & 62 & 24.3 & 52 & 20.4 & 24 & 9.4 & 1.15 & 2.83 \\
\hline 12 & $\begin{array}{l}\text { I consider the use of } \\
\text { EIR in the library as } \\
\text { a waste of time }\end{array}$ & 48 & 18.8 & 104 & 40.8 & 33 & 12.9 & 47 & 18.4 & 23 & 9 & 1.23 & 2.58 \\
\hline 13 & $\begin{array}{l}\text { I think that the use } \\
\text { of electronic } \\
\text { information sources } \\
\text { in the library is very } \\
\text { technical in order to } \\
\text { understand }\end{array}$ & 17 & 6.7 & 49 & 19.2 & 61 & 23.9 & 81 & 31.8 & 46 & 18 & 1.17 & 3.30 \\
\hline & The overall mean and & anda & devia & & & & & & & & & 0.99 & 3.57 \\
\hline
\end{tabular}

